\section{US commercial space companies prepare to fill shuttle vacuum}

\section{Washington}

Although US space launches have decreased dramatically with the suspension of space shuttle flights, the Department of Transportation (DoT) is convinced that commercial launch services are about to take off. The reason for DoT's enthusiasm is an agreement signed last week between Martin Marietta and General Electric to launch $15 \mathrm{GE}$ communications satellites aboard Martin Marietta's Titan rocket over the next several years.

The new agreement was made possible by a shift in US policy regarding commercial satellites that was formulated in 1983 , but only made a reality after the accident to the Challenger space shuttle in 1986.

As originally conceived, the shuttle was to provide launch services to all comers, at a competitive price. But it became clear that a true cost accounting would make launching a satellite aboard the reusable shuttle considerably more expensive than aboard an expendable launch vehicle.

So, beginning in 1984, the Transportation Department was given responsibility for encouraging commercial companies to provide launch services without involving NASA (National Aeronautics and Space Administration) and the shuttle. But NASA remained very much in the commercial launch picture, as even with "total cost recovery", sending a communications satellite into orbit aboard the shuttle was approximately $\$ 10$ million cheaper than any commercial alternative.

But the Challenger accident changed all that. Companies seeking to launch satellites scrambled for launch vehicles. US rocket manufacturers were not prepared to take up the slack, so US companies explored the possibility of using Soviet, Chinese and French rockets.

In the summer of 1986, President Reagan announced that the shuttle was permanently out of the commercial launch business. That announcement made it clear that the future of commercial launches would lie with the private sector.

Richard E. Brackeen, president of Martin Marietta's commercial space launch subsidiary, calls the GE agreement a "benchmark order". Four additional satellite have also been committed to Titan launches. General Dynamics has signed agreements to launch three weather satellites for the National Oceanic and Atmospheric Administration aboard its Atlas rocket, as well as a Euro-

\section{Correction: King Faisal prize}

Professor M. Greaves, joint winner of the $£ 50,000$ King Faisal International Prize for medicine, is at the Leukaemia Research Fund Centre at the Institute for Cancer Research (see Nature 331, 293; 1988). pean telecommunications satellite. McDonnell Douglas will also launch commercial payloads aboard its Delta rocket, including 2 satellites for British television.

In addition to the aerospace giants, some smaller companies are looking for a toehold in the competitive space launch

\section{Soviets pay a rare visit}

Las Vegas

THE United States and the Soviet Union last week completed the "first practical steps" on a quest to verify superpower underground nuclear weapons tests when a 20-member Soviet team ended a five-day visit to the Nevada Test Site, 65 miles north-west of Las Vegas. The Soviet visit follows a visit by a US delegation earlier in January to the Soviet test site at Semipalatinsk.

Now that both sides have seen each other's remote, top-secret nuclear test sites, details of an agreement to explode up to a 150-kiloton nuclear weapon on both sides in order to experiment with measuring devices will come from negotiations in Geneva continuing on 15 February, according to a joint statement. Joint experiments could begin as soon as May.

Dr Robert Barker, the physicist who led the US delegation, said the two scientific teams "exchanged more than words" Soviet Foreign Minister Igor Palenykh, head of the Soviet team, said the process created more trust between the two countries, possibly leading to more agreements.

The joint experiments are intended to enable both sides to agree on improved verification measures necessary to ratify the US-Soviet Threshold Test Ban Treaty of 1974 and Peaceful Nuclear Explosions Treaty of 1976. At least one test on each site is planned.

Both sides agreed to study several ways to measure tests. The methods include US-supported CORRTEX (Continuous Reflectometry for Radiation versus Time Experiment), plus the Soviet hydrodynamic and seismic models.

During the visit, the two delegations exchanged samples of monitoring wires and materials used to plug holes preventing radiation from escaping from underground caverns where nuclear weapons explode.

These small steps, delegates said, could lead to future agreements limiting nuclear tests, and perhaps paring superpower nuclear arsenals. arena. Space Services, American Rocket Company and Conatec are all involved in development programmes.

The next stage in the 'privatization' of space will be clearer when the White House announces details of its new space policy signed by the president last month. In addition to calling for further exploration of Mars and and the Moon, it gives a significant boost to the Industrial Space Facility, a far less expensive but more limited commercial version of the NASA space station.

Joseph Palca

\section{India-USSR collaboration}

\section{New Delhi}

Negotiations have reached an advanced stage between India and the Soviet Union on the establishment of an international space centre in India. The idea was suggested by the Soviet Union in November 1986, and since then the Indian government has been examining the implications.

Science Minister Mr K.R. Narayanan recently told parliament that the Indian response to the Soviet offer will depend on "the need for international cooperation for peaceful uses of outer space consistent with our commitment to self-reliance". He said that discussions had taken place between the two countries and a decision would be taken "after all details regarding the scope and financial arrangements are defined, and the acceptability of such a centre by the international community is clearly established". Any arrangement between India and the Soviet Union on the space centre "will necessarily take into account the security implications and ensure that our own programme does not get affected".

The Soviet proposal is for an integrated space complex with launch facilities for manned and unmanned flights, laboratories for applied space activities, and training of scientists and astronauts from different countries. According to Indian officials, the details are still being worked out.

The Soviet Union is also awaiting the Indian response to its offer of a 1,000-MW nuclear power plant of the VVER type. India has accepted the offer in principle and negotiations are going on over reactor safety and international safeguard issues. According to the chairman of the Indian Atomic Energy Commission (AEC), Dr M.R. Srinivasan, import of the pressurized light-water reactor burning enriched uranium will not affect India's own nuclear programme based on CANDU reactors using natural uranium and heavy water. But critics, including former AEC chairman Dr Raja Ramanna, disagree. The Soviet Union, which recently leased one of its nuclear submarines to the Indian navy is, however, confident that the sale will go through.
K.S. Jayaraman 